\title{
Cultivation of English Teaching Ability for Preschool Students of English Education Major
}

\author{
Dan Guo \\ School of Foreign Languages \\ Anshan Normal University \\ Anshan, China \\ Email: guodanxuri@126.com
}

\begin{abstract}
At present, the qualified preschool English teacher is the key factor that we run English education in the kindergarten, but this is also the most difficult problem that we are urgent to solve. By investigating and doing present situation research about specialized quality of kindergarten English teachers in Anshan, this paper discusses the existed problems, and puts forward the training content, training measures and implementation methods of such professional teaching skills.
\end{abstract}

Keywords-Preschool English teachers; Professional teaching skills; Training content; Training measures

\section{INTRODUCTION}

With the deepening of the reform and opening up and the strong promotion of the concept of quality education, English education for young children has rapidly developed and flourished, which has been widely recognized by teachers, parents, kindergartens, and educational management. It has become an emerging discipline in the field of early childhood education and one of the fastest growing and most popular preschool education practices. Many kindergartens have set up special courses in English, some of which are bilingual kindergartens. Some foreign language schools and after-class foreign language classes have also emerged like mushrooms. Children's English has become the main content of China's enlightenment education.

However, the professional quality of preschool English teachers is still the main bottleneck affecting children's English education. Qualified infant English teachers are the determinants of the opening of English education in kindergartens, and this is exactly the most urgent problem we need to solve. The key is how to ensure the quality of English education for young children and the quality of teachers. At present, young children's English education is in urgent need of a combination of talents with good preschool education skills and excellent English skills [1].

In the past, as a reserve team of primary and secondary school teachers, normal college English education normal students will become the backbone of primary and secondary school teachers after graduation. But the age of 4-8 is the key period for the development of young children's language. Enlightenment education is particularly important. Therefore, English education should be started from the kindergarten stage.
How to cultivate a large number of graduates with high-quality and high professional skills is related to the quality of education in our country's normal universities. Thousands of questions about the quality of early childhood education.

In order to solve a series of problems in the children's English education, some suggestions on how to improve the professional qualities of the children's English teachers are put forward: Strengthen the cultivation of professional emotional qualities for kindergarten English teachers; strengthen the learning of teachers' professional knowledge and the development of professional abilities; Effectively implement early childhood education, scientific research and teaching and research activities; strengthen the cultivation of reserve forces for teachers; and implement a system of kindergarten English teacher qualifications.

\section{The Status QuO AND PROBLEMS OF PRESCHOOL ENGLISH EDUCATION DEVELOPMENT}

Since our country's reform and opening up, the school has established English education from university $\rightarrow$ high school $\rightarrow$ junior high school $\rightarrow$ primary school and kindergarten, and the age level of English education is getting lower and lower. Moreover, the preschool English education in our country continues to expand, and it is developing from big cities to coastal areas to medium and small cities to midwest cities to rural areas. There has been a boom in English education in China. The opening of English classes in kindergartens is in keeping with the trend of the times. In accordance with the needs of reform, opening up, and economic development, we constantly meet the expectations of the society for future talents. According to the survey, most kindergartens now have English education activities. The number of young children learning English is increasing day by day, and the momentum of English teaching activities is increasing day by day. As a result, English education for young children has gone from "fashion" to "formation of an upsurge" to "widespread popularity". It has become an indisputable fact that English classes have generally been set up in kindergartens in major, medium, and small cities in China. However, the quality of preschool English teachers is still the main bottleneck affecting children's English education. The professional quality of teachers is the core of the quality of teachers. So, how to improve the professional quality of preschool English teachers 
scientifically and efficiently? This has become a new topic for preschool education research. As a researcher of early childhood education, in the face of "children's English fever", it is necessary to seriously think and actively explore practice.

The research mainly used surveys, interviews, observations, literatures and other research methods to investigate the current situation of professional quality of preschool English teachers in Anshan. The main contents are: The basic situation, professional attitude, professional knowledge, professional ability of the kindergarten English teachers and the teachers' needs for continuing education. The survey found that the basic situation of teachers surveyed is very unevenly distributed; the difference in "professional attitude" is not significant; the "mastery of professional knowledge" is not balanced; and there is a certain difference in "teaching ability". At the same time also found some problems: low professional emotion; professional knowledge literacy is not high; the correct teaching concept has not yet been formed; teaching ability is weak; teaching evaluation methods are relatively single; education and scientific research capabilities are weak [2].

\section{THE PROFESSIONAL QUALITIES OF PRESCHOOL ENGLISH TEACHERS}

Judging from the literature review, the concept of kindergarten English teachers' professional quality and its structure have not yet been clearly defined. In particular, the requirements for the professional qualities of kindergarten English teachers needed for the gradual establishment of English in kindergartens in the new era have not yet found a more comprehensive and systematic exposition. According to the relevant theory of teacher's professional quality and Professor Brow's elaboration of some basic qualities of qualified English teachers [3], qualified English teachers must have two conditions: teachers must be able to provide students with adequate and accurate language input in their business; Teachers must understand and be good at guiding students' learning.

According to the relevant knowledge of the English teaching method and pedagogy, we believe that the general requirements for the professional qualities of preschool English teachers are: owning solid theoretical foundation and comprehensive language level of English education, mastering basic English language knowledge such as pronunciation, vocabulary, grammar, and cultural background knowledge; has solid basic language skills such as listening, speaking, reading and writing; and can skillfully use English Organize English teaching activities; Has the ability to sing and dance; Can write good artistic skills; Can create a rich, real, harmonious English learning environment; With teaching design, implementation of classroom teaching activities, production and use of a variety of teaching methods and other strong teaching ability Good psychological quality; especially natural oral fluency, voice and intonation standards, etc. All in all, solid professional knowledge and strong professional skills, more systematic modern language knowledge, foreign language teaching method knowledge and education and scientific research skills are the necessary professional qualities for young English teachers.

\section{Cultivation of English Teaching ABility FOR} PRESCHOOL STUDENTS OF ENGLISH EDUCATION MAJOR

The author believes that in order to truly carry out early childhood education and improve the professional quality of young English teachers, it is necessary to strictly control the teacher's qualifications and the training of masters must be added. Therefore, the content of pre-school English education students' professional skills training should include strengthening the cultivation of the professional emotional qualities of preschool English teachers, English professional skills and subject teaching skills.

\section{A. Strengthen the Training of Preschool English Teachers' Professional Emotional Quality}

Traditional teaching education often ignores the emotional education of normal school students. For today's preschool education, teachers, especially humanities teachers, have far more than just professional knowledge and teaching skills. They should also possess equally important qualitiesteachers' emotions, attitudes, and the ability to handle interpersonal relationships. Compared with the acquisition of knowledge and skills, the cultivation of the emotional quality of normal school students is a more complicated and long-term process.

The educational goals can be set as follows: First, it is to cultivate normal education concepts, educational values, and good personality qualities for normal students. Including: love and loyalty to education; have the right self-concept and be able to treat yourself with a positive attitude; Have lofty ideals and personal interests; be able to treat students with equality, goodwill, love, etc.; be good at understanding other people's perceptions, emotions, desires, sharing their emotions and further guide their behavior accordingly. The second is to enable normal students to have good emotional communication skills and skills. Including: Be good at observing and recognizing students' emotional reactions, and respond appropriately; Good at accepting students' emotions and openly and flexibly dealing with their emotional discharge; Being able to naturally get along with students and communicating emotionally; Good at using language, posture, Gestures and other means encourage and arouse students' positive emotions, guide students' emotional direction and control their emotional intensity; they are good at encouraging language and use punitive language with caution; Good at creating a positive and emotional atmosphere, with a sense of humor; able to resolve student emotions, emotional confusion. We can infiltrate and transform the emotional factors in the teaching content of the existing humanities through the creation of emotional courses, so as to infiltrate the emotional qualities into teaching.

The cultivation of emotional quality is incorporated into the entire teacher education program, and the "emotional teacher education" model is constructed and emotional education is implemented. This will lay the foundation for normal students to move toward education jobs and assume the important task of training all-round successors to the socialist cause. 


\section{B. Teachers' professional knowledge learning and professional competence training}

The advantages of teachers of English majors in normal education are: solid professional knowledge in English, oral fluency, phonological standards, correct tone, etc. However, they also have disadvantages: they lack the basic background of early childhood education, and they have not systematically studied early childhood pedagogy and psychology. Such related knowledge, not familiar with the rules of early childhood education and teaching, can not master children's teaching methods, skills and skills. Therefore, for teachers who graduate from English majors, the focus of training is on early childhood education. The specific approach is as follows:

Specializes in preschool education experts, professors, and outstanding preschool teachers, and conducts classroom-style training for English majors, focusing on theoretical knowledge in preschool psychology, early childhood education, etc. Understand the characteristics of children's physiology and psychological development, grasp the organizational skills and implementation skills of early childhood education, so that they can adapt to and be more competent in the practice of English education targeting young children; organize training and discussion of teaching methods, and actively guide them to teaching Innovative design and experiment of methods, teaching techniques, teaching methods. The specific requirements and objectives for the training of early childhood English teaching ability for EFL students are as follows:

Basic professional knowledge and basic skills strive to be concise and practical. For young English teachers, solid professional skills mainly refer to skilled mastering of listening, speaking, reading, and writing skills. Teachers in the daily communication and classroom teaching can correctly use voice, intonation, accurate use of vocabulary, sentence construction and standardization. Taking the first-year students of teachers colleges as an example, the various professional skills required to be achieved are as follows.

Vocabulary: Mastering 4,000 to 5,000 words, as well as common phrases composed of these words (including 2,000 words and phrases held in secondary school), and recognizing new words according to the basic word formation method.

Reading ability: Read articles that are equivalent to reader's Digest's general themes, master the main ideas, and explain the facts and details of the center's carelessness. Can analyze, reason and judge, understand the author's viewpoints and attitudes, and achieve reading speeds. 70 to 120 words per minute.

Listening: Can understand English teachers' lectures, and can understand brief conversations or reports with simple themes, fewer words, and speech rates of 130 to 150 words per minute. [4]Grasp the big ideas and related details and comprehend the speaker's opinions and attitudes.

Oral expression: Can use ordinary conversation in English, can make short speeches on familiar topics, be proficient in English language classes, can ask questions and repeat about teaching materials and appropriate listening materials, and can The lecture was given within a limited time according to the given topic, and the content of the thought was clear. There was no major grammatical error, and the speech and intonation were basically correct.

Written expression: Can take notes, answer questions, write outlines on written materials, write 120 to 150 words in 30 minutes for certain topics or outlines, can rewrite or abbreviate texts, write short messages and notes, express meanings Clear, no major language mistakes.

The comprehensive subject teaching skills mainly refer to the instructors must have the basic skills necessary for English teaching in primary schools. Specific forms of expression may include writing, drawing, singing, performances, teaching aids, instructional design skills, and the like [5]. The same applies to first-year students of English education majors in normal colleges and universities. The objectives of teaching skills for each subject should be as follows.

Writing in English: Proficient in the rules and requirements of hard pen writing (chalk and pen). Can use italics and primary school to complete writing content within the specified time, and the posture is correct, the stroke order is normal, the inclination of the letters is consistent, and the punctuation marks and the first line indentation conform to the format requirements [6].

Creation of stylistic paintings: According to the teaching content, it is necessary to create quick and simple strokes. The pattern meets the given target of language learning. The form is vivid and vivid, and the scale is moderate. The humor is vivid.

Singing in English Songs: The English songs in the current primary school textbooks will be performed in a complete and skillful manner. The tone of the voice is correct, the melody is accurate, and the rhythm is correct. With the ability to teach simple English songs, according to teaching needs, selfeducation, self-revise lyrics, and accurate words, the lyrics can be consistent with the melody, music segment.

Arranging English short plays: Can perform a distinctive character in English, can rewrite or even create a full-length, full-featured English short play. The lines are simple and interesting, and the body language is influential.

Teaching aids production: According to the needs of primary school English teaching, we can produce routine teaching aids and create teaching resource files. Self-made teaching aids should be simple, economical and applicable; the shape, color and proportion of teaching aids should be appropriate.

Instructional Design: Skilled in guiding and guiding lowgrade pupils to learn English phonetics, vocabulary, dialogues, and methods used by high school students to learn discourse. Familiar with elementary English teaching theory and the basic strategies of English teaching in primary schools, we can write lesson plans and design reasonable teaching programs according to the characteristics of Chinese young children learning foreign languages.

In addition to these basic skills, teachers' colleges should also consider improving their English speaking skills and training their computer teaching aids. 
Dual-basic training combined with teaching practice. Training activities can break the traditional model, place specialized training activities in the classroom, use teaching, demonstrations, drills, etc., and teach teachers and trainees to teach interactive teaching methods. Such on-site training enables teachers to receive effective professional guidance and promotion [7].

\section{CONCLUSION}

At present, cultivating young English teachers who are adapted to the development of the 21 st century and have a high level of professional skills for teachers is still an important task for teachers' colleges and universities. In the process of training the pre-professional skills of teachers, normal colleges and universities should also determine the routine assessment methods for students' professional skills, and consider how to establish a series of top-down and effective management mechanisms. Starting from the source, the study on the development of professional skills for preschool English education students will inevitably promote the in-depth development of primary school English teacher education in China.

With the continuous improvement of the requirement for kindergarten English teachers, as the research continues to deepen, the professional quality of young English teachers as professionals will surely have richer connotations. The team of young English teachers will be moving fast and well. The direction of development.

\section{REFERENCES}

[1] Wu Zhendong. A Survey of Preschool Children's English Education Research [J]. Journal of Shenyang Institute of Education, 2005(9):109 112.

[2] Zhang Wengui. Research on the Current Situation and Countermeasures of Kindergarten English Teachers [J]. Preschool education research, 2005(9):15.

[3] Brown, J.D.2001. The Elements of Language Curriculum: A Systematic Approach to Program Development. Foreign Language Teaching and Researching Press, 2001:186-87.

[4] Lin Weihong. On the Development of English Listening in Middle Schools [J]. Basic Education Foreign Language Teaching Research, 2004(8).

[5] Xiao Xi. English teacher professional skills training concise tutorial [M]. Beijing: Higher Education Press, 2002.

[6] Li Pingchang. Questions about writing education in English [J]. Journal of Lianyungang Education College, 1998, (2).

[7] Liu Zhanlan. Theories and Practice Strategies to Promote Preschool Teachers' Professional Development [J]. Beijing: Education Science Press, 2006.31. 